\title{
8 \\ Law, Liberalism, and the Common Good
}

\author{
Jacqueline A. Laing
}

\section{Introduction}

There is a tendency in contemporary jurisprudence to regard political authority and, more particularly, legal intervention in human affairs as having no justification unless it can be defended by what I shall call the principle of modern liberal autonomy (MLA). According to this principle, if consenting adults want to do something, unless it does specific harm to others here and now, the law has no business intervening. Harm to the self and general harm to society can constitute no justification for legal regulation or prohibition. So pervasive is this understanding of legal intervention in human affairs, that it is common now to encounter arguments in favour of permissive laws on, for example, private drug use, pornography, and sexual and reproductive choice, based on the idea that to intervene in these areas would constitute a breach of the liberal ideal.

The only alternative to MLA is assumed to be radical oppression, in which the State intervenes in the individual's life to impose unwarranted measures designed to further its own ends. The legacy of Stalin, Hitler and other modern tyrants has undermined conceptual appeals to the common good. So widespread is this liberal assumption in the Western, English-speaking world that critics of the outlook embodied by MLA are customarily regarded with suspicion and charged with paternalism, narrow-mindedness, and intolerance. Given those unbecoming epithets, one will probably be reluctant to identify oneself as a critic of the prevailing ethos. Nonetheless, highlighting contradictions inherent in the modern liberal tradition is precisely the kind of thing I want to do here. I will be arguing that there is a certain reliance on the notion of the common good within the natural law tradition that may be instructive. 
According to this view, the common good constitutes a mean between two extremes: on the one hand, contemporary liberalism's overinsistence on radical individual autonomy and, on the other hand, totalitarianism's over-emphasis on collective social benefit. There is, I will argue, substantial terrain between the conceptual excesses of modern liberalism and oppressive tyranny that needs to be acknowledged and discussed.

Although there are numerous examples of legal prohibition that (at least implicitly) challenge MLA - such as laws imposing taxation, or prohibiting incest and bigamy between consenting adults, or laws prohibiting drug use and controlling pornography - this chapter will concentrate for the purposes of simplicity on matters surrounding sex, family, and reproduction. I will be arguing that moral and political debates surrounding the family throw up the sorts of question that challenge the very foundations of modern liberalism.

In what immediately follows, two opposing views are outlined. First considered are the claims of liberalism throughout the nineteenth and twentieth centuries. Then I discuss an older outlook, namely the natural law tradition, that depends on the idea that authority is exercised legitimately if it is committed to the common good of society but that to attain this it must employ morally acceptable means. I examine some central trends in that tradition.

I then consider the implications of prohibitions on mass human cloning, incest, bestiality, necrophilia, drug possession, and a number of other activities. An important dilemma facing defenders of MLA is laid bare. Either our commitment to modern liberal versions of individual autonomy will drive us to deny the legitimacy of laws even the fiercest defender of MLA accepts, or we drop our commitment to the contemporary liberal outlook and admit that modern liberalism, at least in its most widely accepted form, fails.

Finally, the roots of self-destruction implicit in the ideology itself are considered. Insofar as liberalism erodes the mechanism of its own survival, the ideology contains the principles that ensure its collapse. It is, I argue, an unsustainable doctrine, if not actually incoherent.

\section{Historical foundations of modern liberal autonomy}

The father of modern liberalism is generally thought to be John Stuart Mill. In his essay On Liberty, Mill formulates what is generally known as the Harm Principle thus: 
The only purpose for which power can be rightfully exercised over any member of a civilised community, against his will, is to prevent harm to others. His own good, either physical or moral, is not a sufficient warrant. He cannot rightfully be compelled to do or forebear because it will be better for him to do so, because it will make him happier, because in the opinion of others, to do so would be wise, or even right. $^{1}$

Liberalism has, in modern times, come narrowly to construe harm and, with it, the role for legal prohibition and regulation. It has been applied to break down a number of social and legal taboos surrounding sex and reproduction. Let us take pornography or homosexuality as examples. The idea is that as we have no evidence of any connection between social or individual harm here and now and pornography, there can be no prohibiting it. Certainly the 'harm to others' principle has been influential in a number of twentieth-century reforms. In 1957 Sir John Wolfenden published his committee's report recommending retention of the offence of soliciting and living off the earnings of prostitution, but decriminalisation of homosexual acts in private. Paragraph 61 of the Report sums up the committee's fundamental philosophy thus:

Unless a deliberate attempt is to be made by society, acting through the agency of the law, to equate the sphere of crime with that of sin, there must remain a realm of private morality and immorality which is, in brief and crude terms, not the law's business. ${ }^{2}$

There is an undeniable truth in this. After all, there are a great many sins or wrongs that go unpunished by the criminal law. I may seethe with murderous thoughts about my neighbour. I may fantasise about bringing about his demise, but if I do not engage my will, if I do not intend and take steps to carry out my desires, either myself or by conspiring with another, my black imaginings will go unpunished by law. I may entertain all manner of arrogant thought. If I do nothing to incite others to crime, then these thoughts will be of no interest to the law. Entertaining these thoughts, although not illegal, may well be regarded as evidence of an underlying vice - pride, perhaps. There is, however, no crime of pride, or anger, or envy, or covetousness simpliciter, at least not until these vices find their expression in some intention to commit a crime together with preparatory acts geared to achieving that end. Wolfenden was surely right to point out that there is a realm of private morality and immorality that is simply not the proper business of the law. 
There are sound reasons why the law should not punish thoughts alone. Punishing immoral thought fails to recognise and reward the self-control that ensures that these thoughts are not acted upon. I may know that I have a tendency for envy or covetousness, and along with them dark fantasies, and I may be trying to control these poor characteristics in myself. To punish me for my thoughts, without giving credit to me for my self-control, fails to recognise worthwhile efforts to avoid immoral action. Moreover, the law has other public interests that morality does not. The means of supplying evidence of these vicious thoughts necessarily involves problematic techniques. The evidence would be purely confessional. There would be few if any public acts to confirm the charge; and so on. Getting evidence of thought crime would be licence for police brutality since confessions would be the sole source of evidence.

There may be good reason not to punish thoughts that are purely private. But it is clear that thoughts that are given public expression in the form of, say, conspiracy, complicity, and attempt are nonetheless routinely regarded as of interest to the criminal law and subject to criminal sanction.

There is then a fundamental truth behind the Wolfenden idea that there must remain a realm of individual vice (whether performed in public or private) 'which is, in brief and crude terms, not the law's business.' To recognise this fact, however, is not to acknowledge the greater claims made by Mill and those who follow him. Nor is it necessarily to accept without qualification the self-regarding/other-regarding distinction traditionally used to promote MLA.

The principle of MLA has been used in the twentieth century to widen the scope of that which is regarded as 'not the law's business.' And so in the West there is a continuing process of decriminalisation and legal accommodation of activities that, at other times and in many other places even now, are thought of as 'undermining the social fabric' and adversely affecting future generations.

The Wolfenden Report generated much public discussion and led to an important ideological exchange now known as the Hart-Devlin debate. In The Enforcement of Morals, ${ }^{3}$ Patrick Devlin argued that ' $[\mathrm{t}] \mathrm{he}$ structure of every society is made up of politics and morals ${ }^{4}$ and more particularly that '[s]ociety is not something that is kept together physically; it is held by the invisible bonds of common thought... The bondage is part of the price of society; and mankind, which needs society, must pay its price. ${ }^{5}$ He was of the view that ' $[\mathrm{t}]$ he suppression of vice is as much the law's business as the suppression of subversive activities. ${ }^{\prime 6}$ 
He argued that 'there must be toleration of the maximum individual freedom that is consistent with the integrity of society ${ }^{17}$ but that tolerance should cease 'where there is a deliberate judgement that the practice is injurious to society. ${ }^{\prime 8}$

Professor Herbert Hart's reply in Law, Liberty and Morality ${ }^{9}$ argued that '[r]ecognition of individual liberty as a value involves, as a minimum, acceptance of the principle that the individual may do what he wants, even if others are distressed when they discover what it is that he does unless, of course, there are other good grounds for forbidding it.. ${ }^{10} \mathrm{He}$ also suggested that Devlin's argument that maintaining moral bonds is essential to preserving society itself, rests on 'an undiscussed assumption...that all morality - sexual morality together with the morality that forbids acts injurious to others such as killing, stealing, and dishonesty - forms a single seamless web, so that those who deviate from any part are likely or perhaps bound to deviate from the whole... But there is no evidence to support, and much to refute, the theory that those who deviate from conventional sexual morality are in other ways hostile to society. ${ }^{11}$

Finally, Hart urged that any society's views about morality will change from time to time, and that it is 'absurd' ${ }^{12}$ to say, as Devlin does, that this means that one society has ceased to exist and another one has taken its place. Changing views about morality may more accurately be compared not with 'the violent overthrow of government but to a peaceful constitutional change in its form, consistent not only with the preservation of a society but with its advance. ${ }^{13}$ Of course, views about morality cannot be infinitely mutable if liberalism is not to amount to an inherently self-contradictory ideology. After all, there are ideologies that are opposed to liberalism. In order to accommodate these differences it is important to understand what liberalism is not. Liberalism cannot be all things to all people if it is not to degenerate into incoherence. The issues raised by Hart in his reply to Devlin will be discussed later in this chapter.

But let us return now to Hart's point about sexual morality. Hart distinguishes between 'sexual morality' and the 'morality that forbids acts injurious to others.' He criticises those who would regard these distinct categories as forming 'a single seamless web' on the ground that he sees 'no evidence to support, and much to refute, the theory that those who deviate from conventional sexual morality are in other ways hostile to society.' Hart's special concern for freedom, then, appears to take matters of sexual morality as primary.

This is the first assumption contained in Hart's critique: the harmto-others principle should be construed narrowly to refer to harms 'here 
and now,' not in terms of broad-ranging notions such as the public interest and the interests of the next generation. The second is that there can be no social harm arising out of sexual activities performed by consenting adults in private. It is in this way that Hart is able to conclude that the law should not interfere with the private acts of consenting homosexuals.

Hart was likewise keen to point out that sexual morality is a matter of convention in a way that other kinds of morality are not, since there is no evidence to suggest that those people possessing what he regarded as unconventional sexual mores were likely to be 'in other ways hostile to society.' It should be understood that defenders of MLA customarily extend the idea of harm 'here and now' to permit legislation prohibiting that which causes shock or offence, here and now, by virtue of being witnessed (e.g. indecent behaviour, offensive billboards, soliciting, and so on). Accordingly, because the immediate offensiveness element is present in the case of soliciting, indecent behaviour, and the like, it falls within the Harm Principle whereas sexual activity in private between consenting adults does not. This element of immediate offensiveness is what distinguishes that which happens 'behind closed doors' between consenting adults from acts that imply a legitimate public interest.

Thus Hart's analysis mirrors what can only be regarded now as mainstream thought in the West. If it makes you happy, and you are consenting adults, and your proposal relates to matters defined by Hart to be private matters, then there should be no legal intervention, indeed possibly there should even be legal accommodation of the chosen activities and lifestyles. The 2004 Civil Partnership Bill, for example, allows same-sex couples to register their partnership and qualify for new rights and privileges. Both the present UK government and the Conservative opposition leader support the proposal, with the latter announcing that permitting same-sex civil partnerships 'recognises and respects the fact many people want to live their lives in different ways. And it is not the job of the state to put barriers in their way. ${ }^{14}$ Despite the dearth of political opposition in the UK, there has been spirited debate about the issue across the Atlantic. In Romer v. Evans ${ }^{15}$ (the case more commonly known as the Colorado Amendment 2 Case), there were vigorous apologetics by defenders and critics of MLA in a case challenging the constitutionality of an amendment to the Colorado Constitution. Amendment 2 aimed to prohibit state and local governments from enacting, adopting, or enforcing 'any statute, regulation, ordinance or policy whereby homosexual, lesbian, or bisexual orientation, conduct, 
practices or relationships [would] constitute... or entitle any person or class of persons to have or claim any minority status, quota preferences, protected status or claim of discrimination.' This proposal was adopted in November 1992 by a vote of 53.4 to 46.6 per cent.

John Finnis was called as an expert witness on behalf of the defendants, the Governor and the State of Colorado, arguing that the state's position was a secular one that traced its roots to the ancient Greeks. Finnis argued that 'all three of the greatest Greek philosophers, Socrates, Plato and Aristotle, regarded homosexual conduct as intrinsically shameful, immoral and indeed depraved... all three rejected the modern linchpin of modern "gay" ideology and lifestyle. ${ }^{16}$ Martha Nussbaum, in her testimony, urged on behalf of the plaintiffs - homosexual activists, civil liberties groups, and representatives from some Colorado municipalities that 'prior to the Christian tradition there is no evidence that natural law theories regarded same-sex erotic attachments as immoral, "unnatural" or improper.' A debate then ensued on whether homosexual acts were regarded by the Greeks, and in particular Plato, as an outrage, a shameless act, or as an adventure, enterprise, or deed of daring. ${ }^{17}$ In the final analysis the majority of the Supreme Court (Scalia J. dissenting) found that Amendment 2 did discriminate against an identifiable class of people and violate their rights to due process and equal protection of law. ${ }^{18}$

In like fashion, the UK's proposals for same-sex civil partnerships assume that it is discriminatory to prevent same-sex partners enjoying the same kinds of privileges open to biologically unrelated heterosexual partners. In so doing, they pave the way for the legal and routine creation of children for same-sex partners using asexual techniques such as in vitro fertilisation. This class of children, needless to say, will be knowingly and deliberately created asexually to live without the love and support of at least one and sometimes both of their biological parents. Where surrogacy is involved, the children will sometimes be removed from their birth mother. Separation from one's blood (and birth) parents, once regarded as a 'damage limitation exercise' (e.g. in cases of extreme danger to the child), in no way chosen when avoidable, will become a legally recognised, chosen, and state-acknowledged way of life. Such separation, already recognised in law on an ad hoc basis with donor insemination and similar techniques, would be logically necessitated and, importantly, guaranteed by the State's recognition of the new family arrangement.

Hart did not make explicit reference in his discussion to reproductive autonomy. His technique, however, of separating sexual matters from matters in which the state has an interest, can and has been extended 
to the reproductive realm. Accordingly, the notion of reproductive (as distinct from sexual) privacy has been used to defend a raft of activities now regarded as standard, for example donor insemination, surrogacy, the freezing of gametes and embryos, and so on. Whether or not Hart would have supported reproductive liberty in the eloquent way in which he defended sexual liberty is a matter of speculation. What can be said with some certainty is that the debate in respect of reproductive liberty and autonomy is conducted in precisely the same way.

Indeed, the concept of sexual and reproductive autonomy is now one of the central and defining features of modern Western liberal society. Moreover, MLA with respect to the sexual and reproductive is a philosophy that fits neatly with a consumer mentality, if for no other reason than that if it does make someone happy there is usually substantial business in it. Whether the industry is in pornography, sex itself, abortion, or fertility, there is usually no small financial incentive involved as well.

That it has come to be widely thought that issues regarding family life, sex, and reproduction are wholly private matters in which the State has no business cannot be doubted. What Hart thought of as unconventional morality - fornication and adultery, de facto 'marriage,' asexual reproduction, and a host of activities once thought irregular - is now regarded as perfectly acceptable. Those who would raise any objection are generally regarded as 'moral fascists', Luddites, or, to put it bluntly, are forgiven as ignorant, first-generation immigrants yet to see the liberal light. Attempts at legal control of these areas of human activity are thought to be aimed at regulating private morality in the same objectionable way as penalising thoughts would be. Accordingly, it is supposed that these areas remain largely within the realm of the self-regarding and so implicitly non-harmful, rather than the other-regarding and therefore potentially harmful. This domain of human behaviour is generally thought to be properly immune from any legal regulation and prohibition deriving from consideration of the common good.

Because taboos surrounding sex, family, and reproduction are regarded as without rational foundation, a host of laws once thought justifiable, and indeed a necessary feature of the law's communicative function, are now thought to be wholly unjustifiable. Laws upholding monogamy and preventing polygamy or punishing bigamy are now beginning to be thought to impinge unnecessarily upon the private. Indeed Hart himself noted that opponents of the bigamy law might 'plausibly urge, in an age of waning faith, that the religious sentiments likely to be offended by the public celebration of a bigamous marriage are no longer widespread or very deep and it is enough that such marriages are 
held legally invalid. ${ }^{19}$ Further, it might now be argued that because in other societies polygamy is permitted, only outmoded Christian taboos, insupportable by liberal values, could explain traditional Western practice. Reproductive and sexual liberty, as we have said, are thought to be an essential feature of MLA. Indeed the prospect of multiple-party same-sex civil partnership arrangements might well constitute the future of the new family. In this intellectual climate so imbued with the assumptions of MLA, only the demand for incest between consenting adults gives the modern liberal pause.

Before concluding this section on the historical foundations of MLA, it is worth remembering that in most other societies now and in the past, it would have seemed most peculiar to assume that the mere characterisation of an activity as one that relates to the sexual or reproductive would be sufficient to take it outside the public sphere and into the domain of the purely private, there to be regarded as an inappropriate subject of restriction or regulation. Behaviour in this realm would have been (and continues widely to be) regarded, on the contrary, as the right and proper subject of restriction if only because the interests of the next generation, of children, of family, and of the tribe were at stake. The very character and spirit of the group or society would have been thought to be involved. Accordingly it would have been unthinkable to hive off the sexual and the reproductive from other areas of legitimate social or political intervention.

It is also worth remembering that, on any view of the matter beyond the familial, there are vast numbers of laws, even now, that interfere with the activities of consenting adults. These laws appear to exist irrespective of whether they are undertaken in private, and irrespective of whether they are thought to involve any direct harm to others here and now. Accordingly, any cursory examination of current English law will yield up offences of incest, bestiality, necrophilia, grave robbery, nondangerous road traffic offences, non-dangerous forgery and counterfeiting, customs and excise offences as well as a host of non-dangerous offences against public justice such as making false statements as to births and deaths, and so on. These offences, appear to exist despite what consenting adults might want to do in private and despite the fact that no harm can be discerned immediately, here and now. We discuss some of these matters in the next section.

\section{The natural law tradition and the common good}

The classical natural law tradition has had little difficulty with the anxieties of modern liberalism. This is so for a variety of reasons. 
Modern liberalism stresses the propensity of individuals to value different things differently, and often aligns itself with both individual and social relativism. The classical natural law tradition generally rejects this understanding of the world. Humans, by use of their reason, are able to understand the natural order inherent in the universe. The natural law tradition also stresses that there is a law that is the same for all people, that is at a certain level of generality, and that can be discerned by proper understanding of our nature. This is so even if there is a substantial portion of human law that is quite properly regarded as different for different peoples and at different times, such laws governing the side of the road on which citizens might travel, laws governing corporations, taxation, planning, and so on.

A second important reason why the supporter of the natural law tradition does not share the worries of the modern liberal is that, in the main, it is a tradition that has a developed sense of the common good. The writings of Plato, Aristotle, Cicero, Augustine, and Aquinas bear this out. Plato writes of the common good as embodied primarily in the virtue - justice - which with temperance, courage, and wisdom permit fellowship between heavens and earth, gods and men. He considers

the mark to which a man should look throughout his life, and all his own endeavours and those of his city he should devote to the single purpose of so acting that justice and temperance shall dwell in him who is to be truly blessed. He should not suffer his appetites to be undisciplined... a mischief without end. For such a man could be dear neither to any other man nor to God, since he is incapable of fellowship, and where there is no fellowship, friendship cannot be. Wise men, Callicles, say that the heavens and the earth, gods and men, are bound together by fellowship and friendship, and order and temperance and justice, and for this reason they call the sum of things the 'ordered' universe, my friend, not the world of disorder or riot. ${ }^{20}$

For Plato, of the two choices of inflicting and suffering wrong, the greater evil is to inflict it, the lesser evil to suffer it. This is because good and evil are not even secondarily understood in terms of individual bodily pleasure, but in terms of 'the ordered universe' in which 'heavens and the earth, gods and men, are bound together by fellowship and friendship.' Of societies built on injustice or jealousy, Plato writes that 'such societies... are no constitutional states, just as enactments, so far as they are not for the common interest of the whole community, are no true laws. ${ }^{21}$ There should be 'no intention of conferring an office 
in ... society on anyone for his wealth, or his possession of some similar advantage, such as physical strength, stature, or family. ${ }^{22}$ It should be for the 'man who is most perfect in obedience to established law, the man whose victory over his fellow citizens takes that form, to whom we should give the function of ministry to the gods, the highest post to him who stands first, the second to him who is next in the contest. ${ }^{23}$ Indeed, Plato says, 'the preservation or ruin of a society depends on this more than on anything else. Where the law is overruled or obsolete, I see destruction hanging over the community; where it is sovereign over the authorities and they its humble servants, I discern the presence of salvation and every blessing heaven sends on a society. ${ }^{24}$

Plato's common good is that which is one with God's law and opposed to 'vanity ... pride of riches or rank or foolish conceit of youthful comeliness.' He who 'needs neither governor nor guide, but is fitted rather to be himself a guide to others... such a one works general confusion by his frantic career.' Although he is thought by some to be great, he is 'left alone, forsaken of God.' It is God 'who... holds in his hands beginning, end, and middle of all that is, moves through the cycle of nature, straight to his end, and ever at his side walks right, the justicer of them that forsake God's law. ${ }^{25}$ In other words, it is God who is the guarantor of justice.

The common good, then, is conceived in eternal terms, not solely in terms of what might produce most satisfaction either to those who would rule or to those who would be ruled. The common good is conceived in terms of the fellowship of heavens and earth, of God and men.

For Aristotle, the political community and public authority are based on human nature and likewise belong to an order established by God. The understanding of this order is to be gleaned from the nature of things, the kinds or species to which individuals belong and the ends proper to them. As Aristotle's well-known proposition at the beginning of the Nicomachean Ethics has it, 'every art and every inquiry, and similarly every action and pursuit, is thought to aim at some good; and for this reason the good has rightly been declared to be that at which all things aim. ${ }^{26}$ All things aim at the good but the good of the community is regarded as the more godlike to attain. This is because 'even if the end is the same for a single man and for a state, that of the state seems at all events something greater and more complete whether to attain or to preserve; though it is worth while to attain the end merely for one man, it is finer and more godlike to attain it for a nation 
or for city-states. These, then, are the ends at which our inquiry aims, since it is political science, in one sense of that term. ${ }^{27}$

But for Aristotle, the art of politics does not rule over the gods any more than virtue presides over philosophic wisdom. This is because politics derives from the gods and virtue derives from philosophic wisdom:

But again [virtue] is not supreme over philosophic wisdom, i.e. over the superior part of us, any more than the art of medicine is over health; ... [f] urther, to maintain its supremacy would be like saying that the art of politics rules the gods because it issues orders about all the affairs of the state. ${ }^{28}$

And good government is neither tyranny, oligarchy, nor democracy, as Aristotle conceives it, because this would amount to corruption of the common good. ${ }^{29}$ Furthermore, the common good is for Aristotle, as for Plato, a matter of friendship between men and God (or the gods) and not confined merely to the transient world of human convention. For Aristotle, the friendship of children to parents, and of men to God, is a relation to them as to something good and superior, 'for they have conferred the greatest benefits, since they are the causes of their being and of their nourishment, and of their education from their birth; and this kind of friendship possesses pleasantness and utility also, more than that of strangers, inasmuch as their life is lived more in common. ${ }^{30}$

For Aquinas, the common good is that for which human society exists, it is the purpose of the human community. ${ }^{31}$ Aquinas believes that human society, like everything else, exists to glorify God. Relative to the members of human society, it exists for the sake of the full flourishing of all of those members. That flourishing, the good of each individual, is dictated by the natural law. It is dictated by what reason determines to be the end or ends toward which God has determined every human to be directed according to his or her rational nature.

For Aquinas, the common good and justice are closely related. Laws are either just or unjust and laws may be said to be just according to their end when they are directed at the common good. These laws are neither excessive nor disproportionate. If indeed laws are just, they have the 'power of binding in conscience, from the eternal law whence they are derived, according to Proverbs 8:15, By Me kings reign, and lawgivers decree just things. ${ }^{\prime 2}$ Laws are said to be just 'both from the end, when, to wit, they are ordained to the common good, - and from their author, that is to say, when the law that is made does not exceed the power of the lawgiver, - and from their form, when, to wit, burdens are 
laid on the subjects, according to an equality of proportion and with a view to the common good. For, since one man is a part of the community, each man, in all that he is and has, belongs to the community; just as a part, in all that it is, belongs to the whole.....33

Laws may be unjust, that is more like acts of violence, by being opposed to the human good in that they are over-burdensome or are not directed at the common good but at the good of the lawmaker, or are disproportionate. These laws do not appear to bind the conscience. Accordingly, Aquinas believes laws are unjust in two ways: 'first, by being contrary to human good, through being opposed to the things mentioned above: - either in respect of the end, as when an authority imposes on his subjects burdensome laws, conducive, not to the common good, but rather to his own cupidity or vainglory; - or in respect of the author, as when a man makes a law that goes beyond the power committed to him; - or in respect of the form, as when burdens are imposed unequally on the community, although with a view to the common good.' All laws of this sort are 'like are acts of violence rather than laws; because, as Augustine says (De Lib. Arb. i.5), "a law that is not just, seems to be no law at all." Wherefore such laws do not bind in conscience..... ${ }^{34}$

Those who understand the individual good properly will also understand that the common good of the family, and of the state or the kingdom, is implied. In other words, seeking the good of the many is precisely seeking the good of the individual since the individual who does not harmonise with the whole of which he is a part offends the principle of unity. Thus Aquinas writes that ' $[\mathrm{h}] \mathrm{e}$ that seeks the good of the many, seeks in consequence his own good. ${ }^{35}$ This is so for two reasons: 'First, because the individual good is impossible without the common good of the family, state, or kingdom... Secondly, because, since man is a part of the home and state, he must needs consider what is good for him by being prudent about the good of the many. ${ }^{36}$ For Aquinas, 'the good disposition of parts depends on their relation to the whole; thus Augustine says (Confess. iii, 8) that "any part which does not harmonize with its whole, is offensive". ${ }^{37}$

Accordingly, for Aquinas, the common good is not understood in purely relativist or subjectivist terms. It is understood as that which allows the destiny of men to be achieved, namely knowledge, love, and service of God. It is a theory that has little difficulty accommodating inter-generational concerns or seeing the need for taboos and prohibitions surrounding sex, family, and reproduction because 'the individual good is impossible without the common good of the family, state, or kingdom ....' 
The classical natural law tradition appears, then, to reject some of the central driving forces behind MLA. It does not regard value as entirely a matter of individual or socially relative preference. On the contrary, it regards value as a mind-independent reality. A substantial part of human law may indeed be different for different people at different times (road rules, planning laws, etc.). But that part does not exhaust the totality of human law. This is so because there is a part of the law that is the same for all people at all times. This part is eternal and unchanging and is closely related to reason and truth. Examples of laws that are eternal and unchanging are those which prohibit the persecution, violation, or destruction of the innocent, and those principles within human law that demand proportionality and equity. For Plato and others in the classical natural law tradition, the common good is conceived in eternal terms, not solely in terms of what brings about, say, the greatest sensory satisfaction either for the ruler or those ruled. The common good is conceived in terms of the fellowship of the heavens and the earth, of gods and men.

In what follows I want to challenge popular versions of MLA. We will see how various examples challenge the principle of sexual and reproductive liberty or autonomy outlined earlier. Liberals will be faced with a dilemma. Either the commitment to this autonomy will prohibit laws purporting to interfere with, for example, mass human cloning (or the creation of animal-human hybrids, consensual incest, bestiality, or consensual cannibalism) or the liberal will have to drop his commitment to sexual and reproductive liberty and admit that MLA, in its most potent form, fails.

\section{Autonomy and its limits}

When Aldous Huxley wrote Brave New World ${ }^{38}$ he described the 'glass and nickel' and the 'bleakly shining porcelain' of the Central London Hatchery and Conditioning Centre. Brave New World painted a fearful picture of a place where human gametes and embryos were screened for flaws, destroyed if imperfect, quality-controlled and mass-produced in incubators. It was clean, clinical, and carefully calculated - and it was utterly inhuman. Huxley's vision of the future was, at the time, a disturbing one. We were invited to contemplate the dehumanised process of reproduction described, as well as the inhuman values that would regard it as normal. Reading the first chapter now, Huxley's imagined world is reminiscent of our own. Ectogenesis (gestation of children outside the womb) is not yet reality, but mass human cloning is virtually 
upon us. It is now commonly thought that so long as the clones are not gestated, there is no inhumanity in the process.

What, it might be asked, have asexual reproduction and the biotechnological reproductive revolution got to do with the Hart-Devlin debate? It is that Huxley's vision challenges the assumption that sex and reproduction are and ought to be somehow immune from public scrutiny because these are purely private matters between commissioning parties or sole reproducers, ${ }^{39}$ as they are now called, and service providers. We cannot regard sex, family, and reproduction as purely private matters when they are entered into by consenting adults, and therefore as being immune from questions relating to the common good.

A man may indeed wish to clone himself one thousand times over. Or he may want to create a group of animal-human hybrids for useful service. Or he may be a doctor motivated by charity and so pleased also to create hundreds of children for consenting, infertile women - using his own sperm. MLA gives us no way of explaining why these desires ought not to be accommodated. If we are to say these kinds of acts are impermissible we need to go beyond the MLA and reach out for other general principles.

Why, it might be asked, should we balk at the prospect of mass human cloning, animal-human hybrids, and remote multiple parenting? After all, is it not mere moral squeamishness that leads us to deny the legitimacy of such developments? Are these not the intuitions of the Luddite or the 'moral fascist'?

The answer to these fundamental questions must be given in terms of the public interest in general and the interests of the next generation in particular. These wider concerns go well beyond those Hart assumed legitimate in Law, Liberty and Morality. They also challenge the two basic assumptions Hart used to question Devlin's argument, namely that (1) the harm-to-others principle should be construed narrowly to refer to harms 'here and now,' rather than broad-ranging notions such as public interest and the interests of the next generation; and (2) there can be no social harm arising out of sexual activities performed by consenting adults in private. On the contrary, I argue, public interest can include such things as the integrity of the individual and the dignity of all human life, respect for women and their dignity as mothers, and other vulnerable groups such as the disabled. ${ }^{40}$ It might also involve recognition of the right to know one's genetic heritage.

Cases are currently being brought in the UK by children born of the fertility industry who want to know fundamental information about themselves. In Rose and Another v. Secretary for Health and Human 
Fertilisation and Embryology Authority ${ }^{41}$ two claimants, Joanna Rose, an adult and E.M., a child represented by her mother, sought any available information about their biological parents. In the course of the case Joanna Rose was, catastrophically for her, advised that this crucial information about herself had been destroyed by the clinic involved.

In a preliminary hearing before the High Court, Mr Justice Scott Baker, himself one of the architects of the Human Fertilization and Embryology Act 1990, concluded that 'Article 8 of the ECHR [European Convention on Human Rights, article protecting private and family life] is engaged in the circumstances of these claimants. ${ }^{42}$ Whether there has been any breach of the convention has, at the time of writing, yet to be determined. In the course of his judgement, Mr Scott Baker outlined the need of one of the plaintiffs, Ms Rose, to know her true identity. Joanna Rose, in her affidavit, described the position of the child born of donor insemination. This class of individuals, unlike all other people in the UK, has no right to fundamental information about themselves, their parents, relatives, medical inheritance, and race. Fertility clinics often have control of such information and are unwilling to release it despite the significance of that information to the children they have created. Whereas it is an offence to falsify the birth certificate of every other child in the $\mathrm{UK}^{43}$ children born of the fertility industry are offered no such protection. Joanna Rose, in her affidavit, suggests that there can be no resolution of her grief as she can only assume that her relatives are still alive. There is no comfort for her since there is no social recognition of the depth of her loss; rather, it has been assumed that this class of people has no right to complain because they owe their very lives to these techniques. Rose points out that she lives with the uncertainty of reunion, the very real possibility of passing her father or siblings on the street and indeed marrying one of them. She wonders whether they would recognise one another. She wonders whether her relatives think of her and whether they could meet. She describes the business of having used her social father's medical history as her own when in fact it has no conceivable relevance to her at all, and discusses the danger involved in medical misinformation.

I have a strong need to discover what most people take for granted. While I was conceived to heal the pain of others (i.e. my parents' inability to conceive children naturally) I do not feel that there are sufficient attempts to heal my pain. ${ }^{44}$

Whilst it appears the case concerns the right to information, it is clear from Joanna Rose's evidence, and the nature of the whole case, that 
much more is at stake. One issue concerns the implications of permitting techniques that systematise asexual reproduction, particularly when the technique deliberately fragments the child's origins from conception. When the state legitimises these reproductive methods, it arguably creates arbitrary and irrational exceptions in respect of certain classes of people. Accordingly, this class could be systematically deprived of information about themselves, unlike all others. Moreover, this class could be created in ways, chosen and avoidable from the outset, that took it for granted that they would not need the love and support of their blood or birth parents. (The deliberate and avoidable nature of the activity is important.) This class could be created asexually and frozen (cryo-preserved), with multiple siblings involved. Such a class of people could be expected, unrealistically, to feel neither loss concerning their asexual beginnings nor any sense of confusion about multiple, unknown siblings, lost family, and separation by time, space, and cryo-preservation. This class of people might be created of parents long dead and yet be expected to suffer no loss, anger, or grief. Such people would be expected to suppress complaint on the grounds that they owed their existence to these artificial reproductive techniques and that many other people are also separated from their blood families by circumstance or necessity.

Nevertheless, the argument that the child born of these techniques has no right to complain since she owes her existence to them contains a profound non sequitur. A child born of abusive reproductive techniques, such as incest (where there is legislative prohibition), need feel no moral indebtedness to incest as a means of reproduction nor feel obliged to agree that incest is morally acceptable. Moreover, of fundamental importance to these reproductive developments, now routinely justified on the basis of MLA, is precisely that they are chosen (though avoidable), deliberate, systematised, and permitted routinely by the state. The argument that many children are separated from their blood families by circumstance or necessity, hence children born of donor gametes should not feel aggrieved, holds little sway. Homicide is not the same kind of loss as natural or accidental death: one suffers an extra kind of grief and loss when one learns, not merely that a loved one has died, but that they have been murdered. Systematic homicide involves even a further dimension of wrongdoing. Likewise, loss of one's biological parents through death or necessity is unlike the same loss that is avoidable yet chosen for a child, and moreover systematised and legally sanctioned by the state.

Let us return to our examples of the man who wants to clone himself several times over, or create animal-human hybrids, or father hundreds 
of children. There may be a number of social reasons why permitting these acts would be an imprudent path for society to adopt: it might inhibit genetic diversity and thwart the useful mechanisms of natural selection, or perpetuate certain kinds of defects, and so on. But one of the most significant reasons for doubting the good of permitting these kinds of action relates to the interests of the people so conceived. One of the problems for clones derives from the fact that they will have been created precisely to be a genetic replica of another. Replication undermines the sense of uniqueness of the cloned person and creates in the mind of the client clone-creator expectations not ordinarily had of children by parents conceiving naturally. A further problem derives from the societal and family expectation, once they have been created, that clones suppress any identity problems that might arise for them in virtue of the fact that their genetic origins were fragmented from the beginning by never having had any genetic father (a sperm-free conception) or genuine biological mother (the relevant characteristics of the egg are absent). Another arises out of the questions of domination and control exercised over the child's genetic future by the very act of cloning. And problems also arise in virtue of their asexual beginnings, dehumanised in the way Huxley so eloquently described, and the profound fragmentation of their family and kin.

Clones would, after all, be living in the shadow of their prototypes and, to further undermine their uniqueness and individuality, in the case of mass human cloning, they would have to live in the knowledge that they had to establish their uniqueness against a multitude of other clones. If we consider the identity of any particular clone, let us for the sake of argument call her Eve, we see her origins have been quite literally scrambled. If Eve were to be brought up by the woman whose clone she was, her mother would be her genetic 'twin sister,' her social grandparents in a sense her 'genetic parents.' Her social uncles and aunts would be her genetic 'brothers and sisters,' and all because she was the genetic replica of another person. Not only would she have been asexually created, she would be a replica of an existing individual. (Contrast the case of identical twins, where although they might be genetic replicas of one another, the element of domination and control of the their future is ordinarily absent and the time at which replication takes place is limited to the early days after conception. Replication is not 'made to order' for the purpose of satisfying another's desire; it is, rather, a random process that does not occur within a technological framework in which children are used as means to ends.) 
It is a familiar point that we cannot assume human cloning to be entirely safe, since similar experiments in animals ${ }^{45}$ have resulted in gross disability, heart defects and malfunction in growth. But even if we do assume, for the sake of argument, that such physical malfunction can be overcome, there are still sound reasons to suppose that the child created by these means has been created in a wrongful or abusive way. We can see that even the clone has an interest in the manner and mode of her origins. Moreover, these interests cannot be set aside just because she owes her existence to her prototype or to those who asexually replicated her.

The point to be understood from the use of the example of mass human cloning is this. If we are to hold on to the idea that the law ought to intervene to prevent this kind of abuse, we will need to jettison MLA. It is hard to see what version of MLA could perform the conceptual work necessary to demonstrate why legal intervention is desirable. After all, there appears to be no immediate harm or offence done 'here and now' by permitting a man to clone himself a hundred times over where he is able to find consenting parties to assist him in his plan. Whatever conceptual apparatus we use to conclude that legal prohibition is appropriate will, I would argue, need to be derived from a moral world well beyond MLA.

Likewise, if we are to understand why we might balk at the prospect of routine creation of animal-human hybrids, we are going to need to appeal to moral generalities surrounding the interests of the class of children so created, their health, identity, family, and kinship. These generalities will emerge from a moral hinterland well beyond that traversed by MLA.

These paradigm cases of identity fragmentation place in sharp focus the issues concerning people conceived by donor gamete and other asexual reproductive techniques. Although not suffering the same number and kinds of loss as those suffered by clones, there are certain similar questions that arise for children born of both kinds of procedure. Very often, modern intuitions are so affected by notions of reproductive liberty that there is an unwillingness to hear of the concerns, loss, and grief of people conceived by the fertility industry. Their outrage is discounted as unwarranted and unjustifiable. It is often assumed that their sense of loss is best suppressed. So pervasive in contemporary Western society are the dogmas of MLA that they seem to obliterate ordinary human sympathy.

In fact there are, even in Western nations, familiar limits on both sexual and reproductive liberty. There are offences of bigamy ${ }^{46}$ and 
incest even where the parties to the offence are consenting adults. ${ }^{47}$ There are offences of bestiality (whether or not this causes immediate offence to anyone $)^{48}$ and there are offences of sexually interfering with a corpse, again whether or not the dead person would have agreed in life to such interference and whether or not the act causes offence to anyone. ${ }^{49}$ The point of these examples is to challenge the notion adopted by Hart, and developed further in recent times, that sexual morality does not raise matters that imply harm to others in which the law has any business interfering, where the individuals involved are consenting adults.

If there is to be any recognition of the above examples as genuine offences, there will need to be an admission that MLA does not supply the necessary conceptual foundation for legal intervention in these areas. Whatever else is true, MLA cannot be the sole operative principle in determining the proper limits of the law in relation to sex and reproduction. We cannot assume that matters relating to sex and reproduction are intrinsically private, self-regarding matters that are 'not the law's business.' Nor can we assume that in such matters the desires of consenting adults, here and now, are the only relevant factors to be taken into consideration. There are societal interests, of which Devlin spoke so eloquently, and there are the interests of the next generation to be considered.

It is perhaps a little easier, then, to see why other cultures and other peoples have found strange the view that there should be no taboos or legal restrictions surrounding sex and reproduction: these involve the well-being and capacity to flourish of the people or culture, as well as, potentially, its very survival. This touches on Devlin's statement, so jarring to the modern ear, that the 'suppression of vice is as much the law's business as the suppression of subversive activities.' The statement sounds crude to us now, but implies a fundamental truth about the need to consider both the common good and the interests of the next generation in public matters surrounding sex and reproduction. If we are to be able to explain why we need to restrict the desires of the multiple cloner, we need to jettison our commitment to MLA. If we cling to MLA, we have no way of explaining what is wrong with mass human cloning and other abusive ways of creating people, such as incestuous reproduction.

The sexual and reproductive realms are not, however, the only ones that challenge MLA. It is worth remembering that there are a great many other areas of law which appear to contravene the principle. There are offences prohibiting the possession of controlled drugs 
(such as heroin, cocaine, and a multitude of other substances) whether or not the parties in possession are consenting adults, whether or not the harm caused by their use is solely done to the self, and whether or not this possession would allow the adult involved greater freedom to express himself in the manner he, as an individual, thinks fit. The rationale behind criminalising possession of drugs will be framed, if at all, in terms of the common good and the interests of society. Rational debate about whether a substance ought to be regarded as 'controlled,' and how it should be classified, must revolve around the immediacy and scope of the impact of the substance, the propensity of the substance to cause long-term illness whether mental or physical, the likelihood that widespread availability of the substance will interfere with the ordinary life of fellow citizens, as well as the cost to the nation of long-term, freely available use. All of these questions presuppose a realm of rational discussion that is well beyond the scope envisaged by MLA.

Again, a large part of the criminal law is dedicated to non-dangerous road traffic offences. Not only are there offences that do not immediately raise the spectre of danger or harm, such as parking offences, but there are also offences that prohibit driving without a seatbelt or riding a motorbike without a helmet. There might well be rational debate about whether these regulations intrude too deeply into the individual's life in defence of the common good. But such debate, insofar as it accepts the in-principle legitimacy of such laws and regulations, takes it for granted that some intervention is warranted to promote the common good, whether or not such intervention limits the individual's freedom to express himself.

There are, in addition, offences against public justice, whether or not these offences cause any actual harm or affront to others, and irrespective of whether the offender's interest in freedom of expression is thereby limited. False statutory declarations; ${ }^{.0}$ concealment of evidence; ${ }^{51}$ contempt of court; ${ }^{52}$ false statements about births, marriages, and deaths; ${ }^{53}$ and perjury $^{54}$ are offences whether or not there is any third-party victim. It is generally assumed that there is a legitimate category of offence dedicated to the defence of the common good of public justice.

Indeed there are a great many offences relating to the vice of dishonesty which do not depend on the existence of any victim before they take effect. Certain kinds of fraud, counterfeiting, tax offences, forgery: none of these depend essentially on the notion of a victim of harm, whether actual or threatened.

In English law, at least, there is also the contentious offence of assisting suicide whether or not the victim consented. ${ }^{55}$ Likewise, a German 
court recently convicted self-confessed cannibal Armin Meiwes of manslaughter, sentencing him to eight-and-a-half-years in prison. ${ }^{56}$ Meiwes admitted killing and eating Bernd Juergen Brandes after sex and hours of sadomasochism, but insisted his victim had volunteered. The computer technician killed and ate Brandes, whose body parts he froze, after placing an advert on the Internet. He told the court in Kassel that it was the realisation of an ambition he had had since his youth, when he fantasised about consuming classmates. The conviction and punishment of a defendant accused of killing his albeit-willing victim demonstrates that violation of a person's consent is not the only rationale for the prohibition on killing.

Those who hold that such prohibitions are appropriate, despite the victim's consent, will point to the interests of society in criminalising the relevant behaviour. They will make the same kinds of points as those made by Lord Templeman in $R \mathrm{v}$. Brown, a case of conviction for assault between consenting sadomasochists, when he asserted that '[s]ociety is entitled and bound to protect itself from the cult of violence. Pleasure gained from the infliction of pain is an evil thing. Cruelty is uncivilised. ${ }^{57}$ Even the dissenting judge, Lord Slynn, did not dispute that 'if society takes the view that this kind of behaviour, even though sought after and done in private, is either so new or so extensive or so undesirable that it should be brought... within the criminal law, then it [would be] for the legislature to decide. ${ }^{58}$ In other words, society might well have an interest in criminalising such behaviour (since it promoted a cult of violence, threatened the vulnerable, and was generally detrimental to the social fabric) whether or not the adults involved consented to the behaviour and undertook it privately.

In defence of MLA, it might be argued that individuals value things differently and that because one man's virtue is another man's vice it is neither for the courts nor for parliament to judge. On this view, there is no moral objectivity in the virtues or the vices: a life dedicated to consensual cannibalism is equal in value to a life dedicated, for example, to music or medicine. Each to his own, it might be thought. Accordingly, it might be argued, there should be the promotion of genuine autonomy. Laws imposing prohibitions should be limited to those that violate a person's freedom to consent. Since no one's consent is violated in cases such as Brown or Meiwes, and no harm done to anyone else, there should be no state persuasion either way. On this view, there is no moral objectivity except that which attaches to individual consent.

The trouble with this kind of rationale is that it seeks to insist on moral objectivity when it promotes MLA but at the same time denies that 
there can be any genuine moral objectivity at all. Even the proponent of MLA must insist on the moral objectivity of his own position if it is not to degenerate into incoherence. Proponents of MLA, for example, regard the creation of so-called victimless crimes as unjustified and oppressive to the human spirit and are loath to permit offences that entrench traditional conceptions of marriage. They press for moral reform, arguing against this alleged oppression and injustice. It is by meditating upon the details of particular moral positions that we begin to see how moral objectivity is presupposed. This is a familiar objection and one that has been considered at greater length elsewhere. ${ }^{59}$ For our purposes it serves to highlight the inconsistency inherent in MLA, which leads its supporters to attempt arbitrarily to privilege certain moral conclusions at the expense of coherence.

As to consensual acts and the common good, one reason it might be thought proper to prohibit consensual cannibalism is simply that its legalisation licenses homicide, one of the most serious kinds of criminal offence. On this view a market in intentional homicide is contrary to the common good. It endangers the innocent, the vulnerable, and the system of justice itself in significant ways. Since life is necessary for human flourishing of any sort, the deprivation of it constitutes a loss to society, to the family, and to the individual whose life is cut short. The fact that the victim consents to the bringing about of his own death for a cannibalistic or, indeed, any other purpose does not detract from that grave loss. Moreover, the institutional recognition of intentional killing creates dangers to the innocent that a legal system, with its limited powers of detection and proof, cannot eliminate. Favouring the interests of the intentionally homicidal interferes with the interests of the law in protecting its vulnerable members and ensuring injustice can be detected at all. Consent is easily manufactured - where in writing, forged - and acquired by duress or unconscionable means. Where there is state-sanctioned medical killing, for example, the opportunity for systematic and wholesale homicide of the vulnerable, the elderly, or the young - whether for pleasure, monetary gain, spare hospital beds, or organs - becomes a reality. A climate is created in which those who were once professionally obliged to care for and cure vulnerable individuals become instead the very same people who seek out the consent to kill and perform the practice of killing these same vulnerable individuals.

Once a homicide conviction is made to depend on the issue of the victim's consent, the principal means of investigating wrongdoing, namely forensic evidence such as lethal doses of drugs in the body, bodily harms, and the like, disappear as a ground for suspicion in their 
own right. Whilst searching for consent might be an appropriate way of dealing with lesser matters, like criminal damage, theft, and assault, it is a less prudent way of dealing with grave matters which currently attract, proportionally speaking, the most serious penalties. Homicide, all things being equal, attracts graver penalties than non-fatal and property offences.

Accordingly, it would be appropriate to protect the innocent from abuse, and to safeguard the legal system against systematising injustice, precisely by limiting the autonomy of those whose desires threaten these goods. On the position I am defending, the gravity of the offence - the taking of innocent human life - would be a sound reason to regard even consensual homicide as a thing that ought nonetheless to constitute a legal taboo, with all its associated prohibitions. Nothing less than the combined values of life and justice would be at stake. The same might not be said of other forms of vice in which the common good was not threatened. For example, it might be a vice for two consenting adults to meet to enjoy conversations steeped in envy of another's goods, or to engage in conversations that were grossly racist in nature. It would not, however, be appropriate to create legal prohibitions to prohibit such activity. Public goods would not be at stake, in the way that they would be in the case of systematised consensual homicide (whether for cannibalistic or other purposes). In the latter case, the vulnerable, the psychologically unstable, the morally weak, the young, the foolish, and the easily suborned would be the first to find their very lives endangered. As in many other walks of life, a permissive mentality would endanger those least capable of defending themselves.

The recognition that prohibitions are appropriate in the case of consensual homicide (in a way that they are not in the case of racist gossip) arises out of a proper understanding of principles of proportionality, moral similarity and difference of kinds, and of the fundamental human goods. To apply principles of MLA to prohibit legal intervention in respect of consensual homicide on the grounds that 'one man's virtue is another man's vice' suffers from several defects. First and foremost, it disallows proper discussion of the very rational principles that allow us to see individual freedom and consent as fatally undermined by recognition of consensual private homicide in a way they would not in the case of vicious private gossip. We can no longer see how grave a threat is involved, or how difficult it would be to prove any kind of wrongdoing. We blind ourselves to the threat to the vulnerable and, in our effort to protect the freedom of the suicidal, we are prepared to sacrifice the innocent and indeed our very system of detecting injustice and doing justice. 
At the beginning of this chapter it was made clear that there is some truth to Wolfenden's idea that 'there must remain a realm of private morality and immorality which is, in brief and crude terms, not the law's business.' Hart's supposition that the sexual is precisely the limit at which the law's interest should expire, however, is doubtful. There are sound reasons to regard a proper legal approach to the sexual, the reproductive, and other areas of public life as challenging MLA. Furthermore, an understanding of individual and common flourishing allows us the conceptual resources with which to undertake rational debate in the first place.

\section{The self-destructive and totalitarian aspects of liberalism}

The preservation or ruin of society depends on this more than on anything else. Where the law is overruled or obsolete, I see destruction hanging over the community; where it is sovereign over the authorities and they its humble servants, I discern the presence of salvation and every blessing heaven sends on a society. ${ }^{60}$

In the course of his discussion, Lord Devlin argued that there must be 'toleration of the maximum individual freedom that is consistent with the integrity of society,' and that tolerance should cease where 'the practice is injurious to society. ${ }^{61}$ One of Hart's objections to Devlin's worries about societal breakdown was that any society's views about morality will change from time to time, and that it is 'absurd' to say, as Devlin does, that this means that one society has ceased to exist and another one has taken its place. It will be remembered that Hart was of the view that changing opinions about morality may more accurately be compared not to 'the violent overthrow of government but to a peaceful constitutional change in its form, consistent not only with the preservation of a society but with its advance. ${ }^{62}$ This argument in itself is compelling. We change. Society changes. The thought that societal change necessarily entails societal decline cannot be supported logically. Hart was surely right to point out that change is not necessarily deleterious.

There is, however, one matter that neither Devlin nor Hart expressly considered in their respective essays on liberalism, perhaps because the problem did not present itself as starkly in those days as it does now, and perhaps too because they were not concerned with matters of fertility and reproduction. 
Hart's liberalism is now establishment ideology but there are grounds for suspecting that this once-unconventional perspective is running into difficulty. One interesting feature of liberalism is that it appears to go hand in hand with native populations' decline. This may be the result of the fragmentation of what is left of the tribe, viz. the nuclear family, as well as of widespread contraception, abortion, infertility, and the greater atomisation of individuals. Whichever way we look at it, Western liberal societies appear not to be in the business of replacing themselves. One obvious problem with any prevailing ideology in a society that fails to replace itself, is that the society may well be replaced by people who do not adopt the same ideology as those establishmentarians, liberal or otherwise, within it.

That native population decline is a feature of modern Western liberal society cannot be doubted. There has been continuing population decrease, both absolute (leaving aside immigration) and relative, in all Western liberal countries. One U.N. publication, World Population at the Turn of the Century, reports that 'Europe is literally melting away like snow in the sun, slipping from 15.6 per cent of the world population in 1950 to 10.2 per cent in 1985 and 6.4 per cent [projected] in 2025. ${ }^{163}$ The United Nations method of choice for addressing the declining population and creating the numbers necessary for economic survival is replacement migration. ${ }^{64}$ It recommends one million replacement immigrants a year to make up the shortfall in the skilled workforce of the UK and to pay the pensions of an ageing population. Hart spoke with equanimity of changing morality, never explicitly recognising that a potential volte-face in the outlook of Western countries' inhabitants might be entirely at odds with his own liberal ideals. Not all ideologies are logically compatible with liberalism. It cannot be assumed that replacement societies will adopt modern liberalism as their preferred ideology. It is in this environment that the oppressiveness of liberalism is bound to become manifest.

If liberalism can be regarded as containing within it the seeds of its own native population decline, a dwindling liberal establishment will need to cling to power with the use of greater and greater intolerance. Demographic decline and replacement migration is one thing. Ideology replacement, however, is quite another. In order to sustain itself in its death throes there will need to be a powerful use of propaganda and the domination of legal, political, and educational institutions to oust dissent by suppression of alternative views. Universities will not be prepared to entertain legitimate debate. Significant posts in government, media, and in universities will be advertised to liberals, in liberal establishment 
organs, for candidates who are sufficiently liberal ideologues. Schools will teach MLA as a fundamental quasi-religious dogma, all the while observing the destruction of the central pillars upon which all society is founded, namely, family and religion. The ruling elite will increasingly suppress alternative viewpoints and, ironically, those very alternatives to liberalism will all the while exist in ever greater supply by virtue of its need for replacement populations.

What might not have been any problem for a society whose fundamental structures were strong will prove the undoing of a liberal society in decline. And so, for example, public symbols of rejection of MLA will be banned in desperate attempts to entrench a failing ideology. Thus we see in France and Germany the banning of headscarves in schools. This simple item of apparel, a symbol of Islamic feminine modesty and public testimony to the wearer's ultimate allegiance to religion and family, incites sufficient fear in the minds of the declining French liberal establishment that it has thought fit to ban it from schools. Such oppression would never have been considered in a flourishing France whose fundamental structures were intact and whose population was burgeoning. Humanity's need for religious expression would have been respected and understood. In a decaying liberal France, on the other hand, this kind of prohibition constitutes an answer of sorts, albeit an oppressive one, on behalf of an ideology in retreat. Paradoxically, what may have had its origins in a respect for freedom will become a parody of freedom. A false ideology bent on liberty at any cost will take liberty hostage and ransom it as it self-destructs.

In section 3 it was suggested that the classical natural law tradition has within it the conceptual apparatus that allows us properly to understand freedom in society. It rejects the relativist idea that there can be no rational debate about morality because each man has his own value and each culture different customs. It highlights the inherent self-contradiction of such an outlook, for even liberalism seeks to entrench itself as a moral norm. Natural law permits an account of law for human beings that is eternal and unchangeable (whether or not the ruler, ruling elite, or the majority recognise it). It supplies an analysis of morality and law that allows us to regard tyranny and oppression as timelessly and unchangeably unjust extremes. Equally it supplies the mechanism by which we are able to recognise self-destructive ideologies such as MLA for what they are. Individual flourishing is to be found in the common good and this latter, in turn, depends on the true nature of humanity which can be discovered via the use of human reason. 
In the classical tradition, the natural law does not become law because or when it is written down, any more than physical laws become laws when they are understood or published in textbooks. The natural law derives from the eternal source of all things. It is this that allows us to understand oppression and tyranny for what they are.

We noted that there was some truth to the idea that ' $[u] n l e s s . .$. the sphere of crime [can be equated] with that of sin, there must remain a realm of private morality and immorality which is, in brief and crude terms, not the law's business.' Oppressive regimes seek to create thought crimes, to intrude upon the genuinely private, destroying human modesty, constantly monitoring human words and deeds even those of the innocent - as well as suppressing art and originality, and allowing police extensive powers to watch, intervene, and arrest citizens on the basis of supposition. This kind of oppression is a familiar characteristic of a number of tyrannies of the twentieth century. It would be edifying, if somewhat implausible, to believe that it was these kinds of concern that motivated the Wolfenden reforms.

As suggested early in this chapter, there are good grounds for believing that the law should not punish private vice, such as wicked thoughts alone. Punishing immoral thoughts fails to recognise and reward the self-control that ensures that these thoughts are not acted upon. Law is bound up too with questions of evidence, detection and prevention in a way that morality is not. The means of supplying evidence of individual vice, for instance private racist thoughts, necessarily involve problematic techniques (such as obtaining confessional evidence in the absence of public acts) that can endanger the innocent.

To agree that there should be no laws punishing thoughts alone is not, however, to agree that there is no such thing as vice. On the contrary, it presupposes a realm of private vice in which there should be no legal intervention. The reason for this is not that morals are relative or the desires of consenting adults paramount, but that the form of intervention necessary would itself pose a grave threat to the innocent and to the system of justice. It was Augustine who asked: 'What are states without justice but robber bands enlarged?' ${ }^{\prime 65}$ It is precisely the recognition that the state itself may become the wrongdoer that suggests the need for legislative restraint. A much-admired feature of English law is its protection of the innocent by means of principles such as habeas corpus, the presumption of innocence, and the high standards of proof characteristic of criminal cases. The power of the state and its officials to abuse the innocent and perpetrate injustice upon them is appreciated. Permitting state punishment of private vice 
allows the state to intrude upon the lives of the innocent in novel and unjust ways.

It is by understanding the potential threat to the innocent and to justice itself by the recognition of thought crimes, that we begin to discern two opposing excesses. The first is that of MLA (with its false supposition that the sexual, the reproductive, and a host of other activities now argued to be beyond the law's legitimate interest, cannot bear on the public good). The second excess is that of totalitarianism (with its preparedness to sacrifice the innocent in its determination to root out threats to the state). If legal intervention to protect the common good is indeed a mean between two extremes, the idea that certain sexual activities are more akin to 'thought crimes' than to genuinely subversive behaviour is at least, on the face of it, plausible. By contrast, the recognition of homosexual 'marriage', with its promise of systematised means of reproduction that deliberately deprive children of their blood parents, albeit with the consent of all parties to the 'service contract,' unfairly privileges the interests of this generation over those of the next. It does so also with the complicity of the state. It is this sort of concern that fuels existing prohibitions on human cloning, incest, and other abusive means of bringing children into the world.

Elevating the interests of consenting adults at a cost to later generations, on the assumption that these new people will owe their existence to their forebears and thus have no right to complain, is rationally unsustainable. The argument that children born of incest or rape have no ground to reject the legitimacy of the way they were created simply because they owe their very existence to this means is a non sequitur. It is often the case that good emerges from evil. To say so implies neither that the evil means used was not evil to begin with, nor that the innocent beneficiaries of such unjust acts must agree to their moral permissibility. The same idea, that from wickedness and wrongdoing much good may come, is contained in an enchanting and ancient Christian hymn ${ }^{66}$ marvelling that Adam's taking of the forbidden fruit led to the creation of the 'Lady Queen of Heav'n.'

\section{Conclusion}

We have seen a number of ways in which the principle of MLA is challenged by existing English law. Drug possession laws, traffic laws, laws protecting public justice and government, are examples of laws that defend the public interest irrespective of whether the acts regulated or prohibited do harm to others here and now. Likewise, laws preventing 
human cloning and animal-human hybrids demonstrate that there are undoubtedly limits on reproductive liberty in the interests of generations to come. Laws punishing incest, bestiality, and necrophilia (never mind more contentious laws entrenching Christian values such as monogamy) whether or not undertaken behind closed doors challenge the principle of sexual liberty. All threaten MLA. We have observed that many of these laws, in different ways, seek to protect the interests of the vulnerable, the next generation, and the very fabric of society (implicit in institutions such as that of the family, public justice, or government itself).

Modern liberalism prides itself on having secured certain rights and freedoms - to destroy one's self, one's offspring, and collectively to destroy one's culture. Built on the empty rhetoric of relativism and blind to its own de facto subservience to illicit industries, MLA promises the good life and then drives us to individual and collective self-destruction. A suicidal ideology that scorns the very means of its own survival is destined to encounter difficulty. An increasingly atomised and alienated life for a steadily ageing population, desperate for the material security for which it paid by life-long service, will quite literally be supplanted by more robust, life-loving theories and cultures. It is in this context that the tyranny of liberalism with its thought crimes, ceaseless monitoring, persecution of the innocent, and attempts to manufacture and control its own citizens is bound to become manifest.

It might be asked whether scientific and commercial techniques such as cloning and asexual reproduction offer liberalism a safe haven against the self-destruction implicit in its modern embodiment. All the signs are that human cloning, conception using donor gametes, and artificial reproduction in general cannot solve that problem. First and foremost, nurture of a child is a lifelong commitment. It also implies a financial cost that the state could not undertake by itself. The very tenets of liberalism erode the desire, the will, and even the rationale to undertake those kinds of life-altering commitments. As long as there are no privileges that attach to the obligations surrounding child rearing, as long as marriage is regarded as one among many partnership options and marital fidelity, the sine qua non of child support, ridiculed as otiose, as long as sex is routinely separated from babies by contraception, the commitment and labour associated with child rearing will simply not be undertaken by liberal ideologues or those millions of us who have grown up with liberalism's legacy.

By contrast, certain strands of thought within the classical natural law tradition, the earliest articulation of which can be found in the thought of Plato and Aristotle, supply the conceptual mechanism 
that enables us to discover a place of equilibrium between the dual excesses of liberalism and totalitarianism. It is here that a proper understanding of both common and individual flourishing is to be discovered. It is from within the natural law perspective that the self-destructiveness of liberalism and the injustice of totalitarianism may be discerned. As we move into an era of mass human cloning, animal-human hybrids, routine freezing of young human life, and children conceived asexually of parents long dead, it will be vital to turn to the wealth of understanding contained in the classical natural law tradition. ${ }^{67}$

\section{Notes}

1. J.S. Mill, On Liberty (London: Penguin, 1974): 68-9. For an opposing view, see Sir James Fitzjames Stephen, Liberty, Equality, Fraternity and Three Brief Essays (Chicago: University of Chicago Press, 1991 [1873]).

2. Report of the Committee on Homosexual Offences and Prostitution, 1957, Cmd. 247, Par. 61.

3. P. Devlin, The Enforcement of Morals (Oxford: Oxford University Press, 1965).

4. Enforcement: 9.

5. Ibid: 10

6. Ibid: $13-14$.

7. Ibid: 16 .

8. Ibid: 17 .

9. H.L.A. Hart, Law, Liberty and Morality (Oxford: Oxford University Press, 1963) (quotations from 1975 edition).

10. Law: 47.

11. Ibid: $50-1$.

12. Ibid: 51 .

13. Ibid: 52.

14. The Independent, 10 February 2004: 'Howard in U-turn Over Gay Marriages'.

15. Evans et al. v. Romer, Governor of Colorado et al. 882 P. 2d 1335 (1994).

16. John Finnis, "Shameless Acts" in Colorado: Abuse of Scholarship in Constitutional Cases', Academic Questions 7 (1994): 10.

17. John Finnis and Martha Nussbaum, 'Is Homosexual Conduct Wrong? A Philosophical Exchange', in Alan Soble (ed.), The Philosophy of Sex (Lanham: Rowman \& Littlefield, 2004; 4th edn), originally in The New Republic (1993); Finnis, "Shameless acts" in Colorado'; Martha C. Nussbaum, 'The Use \& Abuse of Philosophy in Legal Education', Stanford Law Review 45 (1993): 1627-45; Nussbaum, 'Platonic Love and Colorado Law: The Relevance of Ancient Greek Norms to Modern Sexual Controversies', Virginia Law Review 80 (1994): 1515-1651; Gerard V. Bradley, 'In the Case of Martha Nussbaum', First Things 44 (1994).

18. Romer, Governor of Colorado etal. v. Evans etal. (94-1039), 517 U.S. 620 (1996).

19. Hart, Law: 43. 
20. Plato, Gorgias, 507e-508a, in The Collected Dialogues of Plato, E. Hamilton and H. Cairns (eds) (Princeton: Princeton U.P., 1961) (see Dialogues for notes up to and including 25).

21. Plato, Laws IV, 715b.

22. Ibid., $715 b-c$.

23. Ibid., $715 \mathrm{c}$

24. Ibid., $715 \mathrm{~d}$

25. Ibid., 716a-b. Also 'For the good man 'tis most glorious and good and profitable to happiness of life, aye, and most excellently fit, to do sacrifice and be ever in communion with heaven through prayer and offerings and all manner of worship, but for the evil, entirely the contrary', Laws IV, 716d.

26. Aristotle, Nicomachean Ethics I.1, 1094a, trans. W.D. Ross: The Works of Aristotle, vol. IX, ed. Ross (Oxford: Clarendon Press, 1925).

27. Ethics I.2, 1094b.

28. Ethics VI.13, 1145a.

29. Aristotle, Politics III.7, 1279b, trans. Jowett, The Works of Aristotle, vol. X, ed. Ross (Oxford: Clarendon Press, 1921): 'Of the above-mentioned forms, the perversions are as follows: - of royalty, tyranny; of aristocracy, oligarchy; of constitutional government, democracy. For tyranny is a kind of monarchy which has in view the interest of the monarch only; oligarchy has in view the interest of the wealthy; democracy, of the needy: none of them the common good of all.'

30. Ethics VIII.12, 1162a.

31. St Thomas Aquinas, Summa Theologica I-II, q. 92 a. 1 ad 3: 'The goodness of any part is considered in comparison with the whole; hence Augustine says (Confess. iii) that "unseemly is the part that harmonizes not with the whole." Since then every man is a part of the state, it is impossible that a man be good, unless he be well proportionate to the common good: nor can the whole be well consistent unless its parts be proportionate to it' (trans. Fathers of the English Dominican Province; London: Burns, Oates and Washbourne, 1927 (2nd edn, vol. 8).

32. Summa Theologica I-II, q. 96 a. 4, resp.

33. Loc. cit.

34. Loc. cit.

35. Summa Theologica II-II, q. 47 a. 10 ad 2.

36. Loc. cit.

37. Loc. cit.

38. Aldous Huxley, Brave New World (London: Flamingo, 1994 [1931]): ch. 1.

39. Julian Savulescu, 'Procreative Beneficience: Why We Should Select the Best Children', Bioethics 15 (2002): 413-26. See also John Harris, 'Rights and Reproductive Choice', in John Harris and Soren Holm (eds), The Future of Human Reproduction: Choice and Regulation (Oxford: Oxford University Press, 1998): 5-37.

40. A similar list is suggested by Maureen McTeer in 'A Role for Law in Matters of Morality', McGill Law Journal 40 (1995): 893-903.

41. Rose and Another v. Secretary for Health and Human Fertilisation and Embryology Authority (2002) EWHC 1593 (ADMIN).

42. Article 8(1) states: 'Everyone has the right to respect for his private and family life, his home and his correspondence.' 
43. Perjury Act 1911 , ss. 3-4.

44. See note 41.

45. Dolly, the first sheep to be cloned by scientists, was put down because of her severe disability: 'Dolly the Sheep is dead', The Daily Telegraph, 15 February 2003, p. 1.

46. Offences Against the Person Act 1961, s. 57.

47. Sexual Offences Act 2003, s. 64.

48. Ibid., s. 69.

49. Ibid., s. 70.

50. Perjury Act 1911, s. 5.

51. Criminal Law Act 1967, s. 5.

52. Contempt of Court Act 1981.

53. See note 43.

54. Perjury Act 1911.

55. Suicide Act 1961, s. 2.

56. See global press, 30 January 2004.

57. $R$ v. Brown (1993) 97 Cr. App. R. 44 at 52; (1994) 1 A.C. 212 at 237.

58. Ibid. at pp. 89 and 282. The emphasis is mine. Cf. $R$ v. Wilson (1996) Cr. App. Rep. 241, in which branding one's consenting wife with a hot knife within the confines of the marital home was not regarded as proper matter for criminal investigation or prosecution. Perhaps what distinguished the two cases despite the manifest element of violence was precisely the 'cult' element in the case of Brown.

59. On the inconsistency inherent in moral relativism, see David S. Oderberg, Moral Theory (Oxford: Blackwell, 2002): 19-20, where he also quotes W.V. Quine's remark: 'He [the cultural relativist] cannot proclaim cultural relativism without rising above it, and he cannot rise above it without giving it up' ('On Empirically Equivalent Systems of the World', Erkenntnis 9 (1975): $313-28$ at 327-8).

60 . See note 24 .

61. See notes 7 and 8 .

62. See note 13.

63. World Population at the Turn of the Century (New York: United Nations, 1989): 8.

64. 'Immigrants Needed to Save West from Crisis', The Guardian 22 March 2000. See also: Expert Group Meeting on Policy Responses to Population Ageing and Population Decline, Population Division, Department of Economic and Social Affairs, United Nations Secretariat, New York, 16-18 October 2000.

65. City of God IV. 4: 'Remota itaque iustitia quid sunt regna nisi magna latrocinia?'

66. 'Adam Lay Y-bounden' (c. 1450), in The New Oxford Book of Christian Verse, ed. D. Davie (Oxford: Oxford University Press, 1981): 21. 'Ne had the apple taken been ... Ne hadde never our Lady / A been heaven's queen.'

67. Previous versions of this chapter have been given at the Oxford Jurisprudence Discussion Group and at the Society of Legal Scholars seminar at the University of Birmingham. I would like to thank the participants for their helpful comments, in particular Stephen Shute, John Finnis, and John Gardner. I would also like to thank Hugh Henry and Ian McLeod for lively and profitable discussion of the subject matter. 